\title{
A Study on Cultivating College Students’ Ecological Consciousness
}

\author{
Junhong Tang ${ }^{1}$, Wei Zhang ${ }^{2}$ \\ ${ }^{1}$ The Foreign Language Department, Baoding University, Baoding, China \\ ${ }^{2}$ Educational Administration, Jibei Baoding Electric Power Vocational \& Technical College, Baoding, China \\ Email: jessy09012003@yahoo.com.cn
}

Received January $29^{\text {th }}$, 2013; revised March $2^{\text {nd }}, 2013$; accepted March $20^{\text {th }}, 2013$

Copyright (C) 2013 Junhong Tang, Wei Zhang. This is an open access article distributed under the Creative Commons Attribution License, which permits unrestricted use, distribution, and reproduction in any medium, provided the original work is properly cited.

\begin{abstract}
The aim of this study is to cultivate modern college students' ecological consciousness under the background of current deteriorating ecological crisis. The study shows some college students do not realize the harm of the ecological crisis and are not fully aware that it is each person's duties and responsibilities to relieve even solve the ecological crisis either. The study also conveys most students have realized the importance of ecological consciousness in solving the current ecological crisis. They also would like to gain ecological consciousness and accept the three ways discussed in the part of discussion of cultivating their ecological consciousness. Because college students are the precious source of the world and thus colleges have the special mission of guiding the social trend, developing the social culture and making contributions to spiritual construction, it is absolutely urgent and necessary for colleges to make any effort to cultivate college students' ecological consciousness.
\end{abstract}

Keywords: College Students; Colleges; College Students’ Ecological Consciousness

\section{Introduction}

With the rapid development of science and technology, people's material living standard has been improved so much, but the ecological system of the earth has completely failed to maintain its balance. Nowadays, not only the natural and social ecological crisis appeared, but the spiritual ecological crisis also crawled into the human beings' soul. So the modern people have to face up to both the natural and social ecological crisis and the spiritual ecological crisis. Professor Lu Shuyuan pointed out in his Ecological Research in Literature and Art. that saving people's soul is as important as saving the earth and it is not workable only to depend on the development of science and technology and the scientific management ( $\mathrm{Lu}, 2000)$. At present, it is the high time for modern people to pay much attention to the cultivation of people's ecological consciousness. Ecological consciousness refers to the ethics of love, life, value, appreciation, consuming, etc which is the reflection of the relationships between people and the nature, people and the society, people and the other people and people and themselves.

On the one hand, College students are a unique and prominent group in the social development. College students are young, energetic, active and eager to know the world and improve the world. College students are the precious source of the world. To some extent, we can say college students are the productivity and they will determine the future of the world and college students' ecological consciousness decides the main stream of future ecological consciousness. So colleges must and have to cultivate college students' ecological consciousness and college students' ecological consciousness is so critical that it will lead to the success in dealing with the ecological crisis.
On the other hand, in addition to the basic tasks of teaching and research, colleges are also expected to guide the social trend, develop the social culture and make contributions to spiritual construction. Colleges are the drive power of social development (Tan, 2012). As an important part of the system of social culture, colleges have both the internal academic concern and the external social role (Mu, 2007). Any college does exist in certain society. As one of the institutions of the social organizations, colleges have a close relationship with other social institutions. Although different country has different social system, all the colleges have the same mission which is to serve the society (Gasset, 2006).

In terms of the history of education, college education adapted to the development of the agricultural economy before the capitalism, and after the Industrial Revolution, college education served the development of industrial economy (Kerr, 2001) and the current college education, in the 21st century, should contribute to not only the knowledge economy but the solution to the ecological crisis. Taking the social responsibility of the colleges into consideration, we will find the best way to serve the solution to the ecological crisis for college education is to cultivate college students' ecological consciousness.

\section{Data and Variables}

College students' ecological consciousness determines the main stream of future ecological consciousness. In order to know modern college students' ecological consciousness and to improve the efficiency of cultivating college students' ecological consciousness, I made a survey on college students' ecological consciousness. 
The surveys were conducted during March, 2012 to October, 2012. We handed out 5500 questionnaires and collected 5350 and 5000 are valid. The 5000 college students who answered the CSEC (college students' ecological consciousness) questionnaire are from the age of 18 to 25, in randomly selected in 50 colleges. The CSEC questionnaire contained four parts. They are personal general information, attitudes towards current ecological crisis, ideas of ecological consciousness and ways of cultivating college students' ecological consciousness including natural ecology, social ecology and spiritual ecology. Table 1 lists all the variables used in the study.

\section{Methods and Results}

In order to know college students' attitudes towards current ecological crisis and the cultivation of college students' ecological consciousness, I made a simple descriptive statistics expressed as percentages, which is listed in Table 2.

In Q5, who should take the responsibility of solving the current ecological crisis, $8.46 \%$ college students think leaders should take the responsibility of the current ecological crisis and $7.04 \%$ college students have the idea that administrators are responsible for the ecological crisis. This conveys that $17.33 \%$ college students did not realize it is each person's responsibility to relieve and even solve the ecological crisis. In Q6, who will suffer from the ecological crisis, $82.26 \%$ college students think each person will suffer from the ecological crisis, which means that there are still $17.74 \%$ college students who did not realize the harm and bad effect of current ecological crisis. Fortunately, in Q7, which of the following must and have to acquire the ecological consciousness, $91.55 \%$ college students choose $1=$ each person, which shows $91.55 \%$ college students think each person are supposed to acquire the ecological consciousness.

Taking all the date into account, we are able to easily make a conclusion that it is urgent and necessary to cultivate people's ecological consciousness. Moreover, because of the special characteristics and the critical importance of the college students in the development of the world and the special mission of colleges mentioned in introduction, one of the key points of colleges is to cultivate college students' ecological consciousness.

In Q4, Q8, Q10, Q11, Q12, Q13, 1 = agree very much, 2 = agree a little, 3 = agree, 4 = don't agree. All the date about the former questions was dealt with through SPSS 17.0 and the result is shown in Table 3.

In view of all the means, medians and modes illustrated in Table 3, we can see the college students' attitudes towards current ecological crisis $(\mathrm{Q} 4$ : Mean $=1.88$, Median $=2.05$, Mode $=2$ ), that is to say, most students care about the ecological crisis and they would like to obtain the ecological consciousness (Q8: Mean $=1.97$, Median $=2.13$, Mode $=1$ ) and they accept the three ways $(\mathrm{Q} 10$ : Mean $=2.99$, Median $=2.55$, Mode = 3; Q11: Mean = 2.84, Median = 2.76, Mode = 3; Q12: Mean $=2.77$, Median $=3.00$, Mode $=3$; Q13: Mean $=2.89$, Median $=2.78$, Mode $=3$ ) which will discuss in the part of discussion to cultivate their ecological consciousness.

\section{Discussions}

Three ways of cultivating modern college students' ecological consciousness are discussed in this part.

Each person is thrown into the complex relationship of the
Table 1.

Description of the CSEC questionnaire.

\begin{tabular}{|c|c|}
\hline Variables & Description \\
\hline Q1. Gender & $1=$ female $; 2=$ male \\
\hline Q2. Age & $\begin{array}{l}1=10-17 ; 2=18-25 \\
3=26-33\end{array}$ \\
\hline Q3. Major & $\begin{array}{l}1=\text { arts } ; 2=\text { science; } \\
3=\text { engineering }\end{array}$ \\
\hline $\begin{array}{l}\text { Q4. Attitudes towards current } \\
\text { ecological crisis }\end{array}$ & $\begin{array}{l}\text { Three categories: } \\
1 \text { = care about it very much; } \\
2 \text { = care about it; } \\
3 \text { = care about it a little; } \\
4 \text { = does not care about it at all }\end{array}$ \\
\hline $\begin{array}{l}\text { Q5. Who should take the responsibility } \\
\text { of solving the current ecological crisis? }\end{array}$ & $\begin{array}{l}\text { Four groups of people; } \\
1 \text { = leaders; } 2 \text { = administrators; } \\
3 \text { = the famous and rich person; } \\
4=\text { each person }\end{array}$ \\
\hline $\begin{array}{l}\text { Q6. Who will suffer from the } \\
\text { ecological crisis? }\end{array}$ & $\begin{array}{l}\text { Four groups of people: } \\
1 \text { = leaders; } 2 \text { = administrators; } \\
3 \text { = the famous and rich person; } \\
4=\text { each person }\end{array}$ \\
\hline $\begin{array}{l}\text { Q7. Which of the following must and } \\
\text { have to acquire the ecological } \\
\text { consciousness? }\end{array}$ & $\begin{array}{l}\text { Four categories: } \\
1 \text { = leaders; } 2 \text { = administrators; } \\
3 \text { = the famous and rich person; } \\
4 \text { = each person }\end{array}$ \\
\hline $\begin{array}{l}\text { Q8. Do you agree that each person } \\
\text { should have ecological consciousness? }\end{array}$ & $\begin{array}{l}\text { Four categories: } \\
1 \text { = agree very much; } \\
2 \text { = agree a little; } \\
3 \text { = agree; } 4 \text { = don't agree }\end{array}$ \\
\hline $\begin{array}{l}\text { Q9. Are the human beings able to gain } \\
\text { sustainable development without } \\
\text { ecological consciousness? }\end{array}$ & $\begin{array}{l}\text { Two categories: } \\
1 \text { = Yes; } 2 \text { = No }\end{array}$ \\
\hline $\begin{array}{l}\text { Q10. Do you agree that people's } \\
\text { ecological consciousness can be } \\
\text { cultivated through reading ecological } \\
\text { literature works? }\end{array}$ & $\begin{array}{l}\text { Four categories: } \\
1 \text { = agree very much; } \\
2 \text { = agree a little; } \\
3 \text { = agree; } \\
4 \text { = don't agree }\end{array}$ \\
\hline $\begin{array}{l}\text { Q11. Do you agree that we should pay } \\
\text { more attention to the ecological literature } \\
\text { works in order to cultivate college } \\
\text { students' ecological consciousness? }\end{array}$ & $\begin{array}{l}\text { Four categories: } \\
1 \text { = agree very much; } \\
2 \text { = agree a little; } \\
3 \text { = agree; } \\
4=\text { don't agree }\end{array}$ \\
\hline $\begin{array}{l}\text { Q12. Do you agree it is necessary for } \\
\text { colleges to set up some kind of Soul } \\
\text { Communication Bars to direct college } \\
\text { students' normal spiritual ecological } \\
\text { system? }\end{array}$ & $\begin{array}{l}\text { Four categories: } \\
1 \text { = agree very much; } \\
2 \text { = agree a little; } \\
3 \text { = agree; } \\
4 \text { = don't agree }\end{array}$ \\
\hline $\begin{array}{l}\text { Q13. Do you agree that it is helpful for } \\
\text { colleges to remolding college students' } \\
\text { ecological consciousness in the practice? }\end{array}$ & $\begin{array}{l}\text { Four categories: } \\
1 \text { = agree very much; } \\
2 \text { = agree a little; } \\
3 \text { = agree; } 4 \text { = don't agree }\end{array}$ \\
\hline
\end{tabular}

Note: Source: data from CSEC, 2012.

nature, the society and the individual at the very beginning of his or her life, and he or she begins his or her life progress on the three layers of natural ecology, social ecology and the spiritual ecology (Zhang, 2001). The person is the important hub in the interaction of the three layers. The relationship among the spiritual ecology and the natural and social ecology is dynamic and they influence each other. Only is there a perfect balance among the three layers, the ecological system of the earth could be preserved.

Ecology is a new field with the appearance of ecological crisis. It puts the emphasis on creating a good and healthy ecological environment including the natural ecology, the social 
Table 2.

Descriptive statistics.

\begin{tabular}{|c|c|c|}
\hline Questions & Choices & Percentage \\
\hline \multirow{4}{*}{$\begin{array}{l}\text { Q5. Who should take the } \\
\text { responsibility of solving } \\
\text { the current ecological } \\
\text { crisis? }\end{array}$} & $1=$ leaders & 8.47 \\
\hline & $2=$ administrators & 7.04 \\
\hline & $3=$ the famous and rich person & 1.83 \\
\hline & $4=$ each person & 82.67 \\
\hline \multirow{4}{*}{$\begin{array}{l}\text { Q6. Who will suffer from } \\
\text { the ecological crisis? }\end{array}$} & 1 = leaders & 7.73 \\
\hline & $2=$ administrators & 5.15 \\
\hline & $3=$ the famous and rich person & 4.86 \\
\hline & 4 = each person & 82.26 \\
\hline \multirow{4}{*}{$\begin{array}{l}\text { Q7. Which of the following } \\
\text { must and have to acquire } \\
\text { the ecological } \\
\text { consciousness? }\end{array}$} & 1 = leaders & 3.14 \\
\hline & $2=$ administrators & 1.58 \\
\hline & $3=$ the famous and rich person & 3.73 \\
\hline & 4 = each person & 91.55 \\
\hline
\end{tabular}

Table 3.

Investigation on college students' ecological consciousness.

\begin{tabular}{|c|c|c|c|c|c|}
\hline \multirow{2}{*}{ Questions } & \multicolumn{2}{|c|}{ Number } & \multirow{2}{*}{ Mean } & \multirow{2}{*}{ Median } & \multirow{2}{*}{ Mode } \\
\hline & Valid & Invalid & & & \\
\hline Q4 & 5000 & 0 & 1.88 & 2.05 & 2 \\
\hline Q8 & 5000 & 0 & 1.97 & 2.13 & 1 \\
\hline Q10 & 5000 & 0 & 2.99 & 2.55 & 3 \\
\hline Q11 & 5000 & 0 & 2.84 & 2.76 & 3 \\
\hline Q12 & 5000 & 0 & 2.77 & 3.00 & 3 \\
\hline Q13 & 5000 & 0 & 2.89 & 2.78 & 3 \\
\hline
\end{tabular}

ecology and the spiritual ecology ( $\mathrm{Lu}, 2006)$ so as to obtain the purpose of harmonious development of the nature, the society and the individual.

Ecological education is a very complicate systematic project. It needs the cooperation of many subjects and sectors. Some courses like literature, ethics are expected to play their part in cultivating college students' ecological consciousness. Moreover, Soul Communication Bar is also necessary for the students to get healthy guidance and warm-hearted comfort (Zhang, 2005). It is also helpful for the students to go into the society, to go into the nature after class. In the real life, college students' ecological consciousness will get better improved.

\section{Salvaging College Students' Soul by Means of Ecological Literature}

Because college students have special characteristics, one of the efficient ways to cultivate their ecological consciousness is by means of ecological literature. Literature comes from life, so it can influence people's life to some extent. Literature is such a kind of spiritual weapon that it can affect a person's mind, emotion, behavior, etc. Ecological literature is the author's concern about the ecological crisis, and it is also some kind of reflection on the current ecological crisis. From Table 3, we can see such statistics as Q10: Mean $=2.99$, Median $=2.55$, Mode = 3; Q11: Mean = 2.84, Median $=2.76$, Mode $=3$, which shows most students agree that ecological literature works can help to savage college students' soul and will be helpful for the cultivation of college students' ecological consciousness.

In Moby Dick, people killed the whales not for supporting their families but for meeting their ever-lasting greedy desires. The evil desires finally lead to the completely drown of the ship and all the people on the ship. Moby Dick tells the modern people that we should not exploit the nature excessively and it is very important for us to control our greedy desires. The Great Gatsby also demonstrated people's materialism, alienation and utilitarianism (Sun, 2007). As soon as Rachel Carson's Silent Spring appeared in 1962, it shocked America. In the novel, using a lot of real scientific arguments, Carson showed the threat of the insecticide abuse to people's health and even to the whole ecological environment. In the novel, the author fiercely criticized people's excessively exploitation of the nature under the drive of evil desires.

Through studying some ecological literature, the teacher can call on the students to cherish the nature, wake up the students' ecological intuition and cultivate their ecological consciousness. As a result, the ecological environment will get improved.

\section{Directing College Students' Soul through Creating Soul Communication Bar}

In Table 3, such data as Q12: Mean $=2.77$, Median $=3.00$, Mode $=3$ was shown, so it is necessary and important for the colleges to create some Soul Communication Bar by using the modern science and technology, for example, qq chat, blog. Because such kind of communication styles do not need to communicate face to face, it is easier for the college students to speak out their real feelings and their real problems. College students acknowledged that sometimes they will feel sad, depressed and gloomy. The reason of this bad mood does not come from the learning pressure, but come from the daily life. There does exist some distance between one person to another, but the real and terrible distance is the spiritual distance. Therefore, the related teachers should be fully aware of the chances by means of the Soul Communication Bar to cultivate the college students' ecological love ethics, ecological consume ethics, ecological job-hunting ethics, etc.

In Space of Eco-criticism, professor Lu Shuyuan mentions that except for social and natural ecology a person is also a kind of spiritual ecology in terms of the living conditions of human beings. The spiritual ecology refers to the balance and stability of the spiritual ecological factors such as love ethic, moral ethic, aesthetic ethic, life ethic, etc. Moreover, the spiritual ecological system is the necessary premise and basis of the natural ecological and the social ecological system. Once the balance and the stability of the spiritual factors are disturbed, the spiritual ecological system of a person will be thrown into disorder. Then the spiritual ecological crisis will come into being and the crisis will lead the person to be immoral, abnormal and far away from the right orbit of life.

\section{Remolding College Students' Soul in the Practice}

Practice is the sole criterion for testing truth. Various kinds of activities are a good form to cultivate college students' ecological ethics and they are also easily accepted by the college 
students. As shown in Table 3, Q13: Mean = 2.89, Median = 2.78 , Mode $=3$, organizing college students into the real life is also suitable for the college students' psychology. So the related leaders and teachers of colleges should be fully aware of this and make their effort to cultivate college students' ecological consciousness. On the one hand, let the students enjoy the beautiful nature and harmonious social phenomenon. On the other hand, lead them into some destroyed and polluted places. In the completely contrast, the college students will respect and cherish the nature, the life much more.

At the same time, the related government is expected to make its any effort to improve college students' ecological consciousness; the journalists and the public media are supposed to play their part in this issue: they should keep the college students well-informed of the potential harm of the imbalance of the ecological system; each college student should try his or her best to gain the ecological consciousness.

\section{Conclusion}

\section{It Is Necessary and Practicable to Cultivate College Students' Ecological Consciousness}

Heidegger once said that the earth had become a lost heavenly body and the human beings had lost reason (Bold, 1993). Professor Lu Shuyuan also thinks that modern people's value of current utilitarian, materialistic ethics is the main cause of the modern ecological crisis and the modern society is such a society that people's values has overturned ( $\mathrm{Lu}, 2001)$. Considering this situation, it is very important and necessary to rebuild people's life ethics and cultivate their ecological consciousness.

College students are important power in the future construction of one country and it is easier to cultivate college students' ecological consciousness because of their study place, their study method and their study pattern, so it is a wise, simple way to cultivate college students' ecological consciousness in dealing with the current ecological crisis.

\section{It Is Urgent to Cultivate College Students’ Ecological Consciousness in Current Ecological Crisis}

With the modernization and the rapid development of the science and technology, the human beings exploit the nature so excessively that the nature has been destroyed badly and the balance between the human beings and the nature was also damaged, so the natural ecological crisis appears. The natural crisis includes such phenomena like enlarging desert, shrinking grassland, losing soil, abnormal climate, etc. The natural ecological crisis has limited the long, lasting development of the global economy. Social ecological crisis also appears in the social field because of the heavy life burden and the bad concept of competition. The relationship between one person and another becomes indifferent and it is hard to cooperate with each other sincerely at present. Nowadays, the human beings have lost the feeling of safety, while the utilitarian, materialistic ethics are pervasive.

With the deterioration of the natural and social ecological crisis, people's spiritual ecological crisis came into being and even got worse. Some modern people lost their believes in the face of personal benefits, went astray before temptation and alienated friends and relatives, so the rate of committing suicide, taking drugs, divorce, melancholia, extra-marital relationship has become higher. Just as Joyce said that the modern people conquered the space, the land, the decease and the backward, but all the victories would become one drop of tear in the furnace of spirit.

The spiritual ecological crisis not only has a bad effect on the development of a person but also has an important impact on the development of the natural and social ecological development. Spiritual ecological crisis is the fatal cause of the natural and social ecological crisis. If we want to solve the social and natural crisis, it is the first thing that we deal with spiritual ecological crisis. Taking all these factors into consideration, it is definitely urgent and important to cultivate modern college students' ecological consciousness.

\section{Acknowledgements}

The paper is under the project of the Importance of Ecological Literature in British and American Literature Teaching (SZ123002). All the project members made their contributions to the paper. I also thank all my friends and classmates who live in different cities, which made the investigation possible.

\section{REFERENCES}

Bold, G. S. (1993). Heidegger analysis of the new era of science and technology. Beijing: China Social Sciences Press.

Gasset, O. Y. (2006). Mission of the university (J. Chen, Trans.). Hangzhou: Zhejiang Education Press.

Kerr, C. (2001). High education cannot escape history (C. X. Wang, Tans.). Hangzhou: Zhejiang Education Press.

Lu, S. Y. (2001). Development of spiritual ecological source. Southern Cultural Forumn, 1, 37-42.

Lu, S. Y. (2000). Ecological research in literature and art (p. 32). Taiyuan: People's Education Press.

Lu, S. Y. (2006). The space for ecocriticism. Shanghai: East China Normal University Press.

Mu, Y. F. (2007). Mission and duty of the university. Beijing: Education and Science Press.

Sun, Y., \& Liu, J. F. (2007). The spiritual ecological analysis on The Great Gatsby. Bilingual Learning, 4, 132-134.

Tan, D. L. (2012). The characteristics of modern college students and a study on their growing up. Beijing: People's Press.

Zhang, D. J. (2005). The psychology in education. Beijing: People's Education Press.

Zhang X. L. (2001). From phenomenology to Confucius. Shanghai: Commercial Press. 